\title{
The Implementation of School Literacy Movement by Using Storybook in Elementary School
}

\section{Isnaeni Wahab1*, Nurhadifah Amalivah ${ }^{2}$}

${ }^{1}$ Muslim Maros University, Indonesia

${ }^{2}$ Megarezky University, Indonesia

\section{A R T I C L E IN F O}

Article history:

Received June 15, 2021

Revised June 21, 2021

Accepted July 07, 2021

Available online August 25, 2021

\section{Kata Kunci}

Literasi, Budaya, buku cerita

Keywords:

Literacy, Culture, Story Book

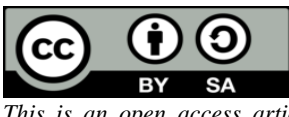

This is an open access article under the CC BY-SA license.

Copyright (ㄷ) 2021 by Author.

Published by Universitas Pendidikan Ganesha.

\begin{abstract}
A B S T R A K
Literasi merupakan salah satu cara membangun dan mengembangkan kemampuan berpikir anak yang penting bagi siswa. Akan tetapi, kebiasaan literasi siswa masih rendah. Oleh sebab itu, sekolah sebagai salah satu tri pusat pendidikan hendaknya menerapkan budaya literasi sebagai upaya untuk meningkatkan kemampuan berpikir anak. Penelitian ini bertujuan untuk mengkaji informasi tentang penerapan budaya literasi di sekolah, dan menerapkan literasi dengan menggunakan cerita anak bagi siswa. Penelitian ini menggunakan pendekatan deskriptif kualitatif dengan metode survei. Subjek penelitian ini adalah siswa Sekolah Dasar. Teknik pengumpulan data melalui observasi, wawancara, dan dokumentasi. Data analisis melalui tahapan reduksi data, penyajian data, dan penarikan kesimpulan. Hasil penelitian menunjukkan bahwa kegiatan literasi di sekolah telah diterapkan dengan literasi lima belas menit sebelum pelajaran dimulai dan menggunakan setiap sudut sekolah sebagai pojok membaca, sedangkan penerapan literasi menggunakan buku cerita dilakukan dengan mengajak siswa membaca buku dengan judul cerita yang bervariasi. Berdasarkan hasil tersebut, dapat disimpulkan bahwa sekolah dasar sudah memiliki program literasi yang baik dan penerapan literasi menggunakan buku cerita mampu mengajak siswa untuk menceritakan kembali isi cerita dan nilai moral cerita. Implikasi penelitian ini yaitu sekolah hendaknya mengoptimalkan perannya sebagai salah satu dari tri pusat pendidikan untuk membangun dan mengembangkan kebiasaan literasi bagi siswa sekolah dasar.
\end{abstract}

A B S T R A C T

Literacy is one way to build and develop children's thinking skills that are important for students. However, students' literacy habits are still low. Therefore, schools as one of the three educational centers should implement a literacy culture to improve children's thinking skills. This study aims to examine information about the application of literacy culture in schools and to apply literacy using children's stories for students. This study uses a qualitative descriptive approach with a survey method. The subjects of this study were elementary school students. Data collection techniques through observation, interviews, and documentation. Data analysis through the stages of data reduction, data presentation, and concluding. The results showed that literacy activities in schools had been implemented with literacy fifteen minutes before the lesson started and used every corner of the school as a reading corner, while the implementation of literacy using storybooks was done by inviting students to read books with various story titles. Based on these results, it can be concluded that elementary schools already have a good literacy program and the application of literacy using storybooks can invite students to retell the story content and the moral values of the story. This research implies that schools should optimize their role as one of the three educational centers to build and develop literacy habits for elementary school students.

\section{INTRODUCTION}

Reading is an activity to gain various knowledge and development of information technology. Various efforts have been made to cultivate reading culture from an early age, one of which is through the school literacy movement. But unfortunately, the reality shows otherwise. The low literacy and writing culture of the Indonesian people is a national problem that must be addressed and resolved immediately. Reading habits or literacy in Indonesia are still low (Kastro, 2020; Khotimah et al., 2018; Suyono et al., 2017). Based on the results of a survey conducted by UNESCO on ASEAN countries in 2011, it was found that Indonesia was in the lowest rank with a value of 0.001 . This data shows that out of around 1000 Indonesians, only one has a high reading culture (Silvia \& Djuanda, 2017; Yunianika \& Suratinah, 2019). The impact of ability low reading definitely affect the lack of knowledge from various aspects. Therefore to improve the reading ability and interest in our country, the government through the Ministry of Education and Culture launched the School Literacy Movement. 
Literacy movement is an activity to process and understand information while reading. This is one way to build and develop children's thinking power. Literacy directs a person to understand messages that are manifested in various forms of text (oral, written, visual) (Arini et al., 2020; Tryanasari et al., 2017; Warsihna, 2016). By implementing literacy movement, students can improve their access to information, so that the students can open their insights and knowledge (Arini et al., 2020; Izati et al., 2018; Suyono et al., 2017). Literacy is a form of development and needs in this current developments. Literacy as a form of ability that is given as a provision for students is another answer to the challenges that exist today and the future. With the ability to read, of course, you will be able to predict a number of things, so you do not make a mistake and become the golden generation as expected. Literacy as the use of practices in social, historical, and cultural situations in creating and interpreting meaning through texts. Literacy as the basis for developing effective and productive learning allows students to be skilled in finding and processing information that is needed in a science-based life in the 21st century (Suyono, 2011; Suyono et al., 2017). Ability to read and writing can be optimized at school through literacy activities (Suyono et al., 2017). Therefore, literacy habits at school must be improved and made a habit at school.

Schools are the most expected facilities to increase reading interest among students. Some things that can be done according to government recommendations are the implementation of fifteen minutes of reading. One of the activities in literacy is 15-minute activity of reading non-lesson books before learning time begins, and it is carried out in order to foster student interest in reading and improve reading skills so that knowledge can be mastered better (Kartini \& Yuhana, 2019; Syawaluddin \& Nurhaedah, 2017). The most effective time to apply literacy is before entering the core lesson. The pre-reading stage is intended to increase reading motivation and activate reader's schemata (Nurhadi, 2016). Furthemore, The important thing that needs to be done by schools is to build a literate-rich physical school environment, including providing school libraries, reading corners, reading gardens, and fun child-friendly areas (Kastro, 2020; Khotimah et al., 2018). In addition, a research stated that the implementation of the School Literacy Movement at SDN Bumiwaras can be done through integration in the learning process, such as reading aloud or reading silently, placing the classroom as a literacy room by attaching images of heroes, slogans, and so on (Erniyanti, 2018). Literacy culture implies that information literacy efforts as the definition of literacy itself must become a habit for students in primary schools in particular and at other levels of education in general. A habit that is carried out continuously will become a culture and will eventually become a culture. Therefore, literacy can be presented as a culture for the Indonesian people, especially for students in elementary schools.

The implementation of literacy still has various obstacles. One of the factors is the lack of interest in reading. This is closely related to the lack of availability of various types of books around them. The implementation of literacy problems in school due to lack of availability of books in the school library (Novarina et al., 2019; Yulianti et al., 2018). In addition, several studies have found that several inhibiting factors for increasing interest in reading today include the scarcity of interesting book that is published in the country, and the lack of availability of free reading parks with complete and interesting book collections (Agustin \& Cahyono, 2017). It was also said that the number of books available is still very limited and not varied (Yunianika \& Suratinah, 2019). Therefore, a solution is needed to deal with it. In this research, the implementation of literacy was carried out using story books with various folklore titles prepared by the researchers because most books in schools just about knowledge. Researchers use story books because as we know that story books contain moral values and character that are needed by children, especially elementary school students as the basis for forming a good generation later. Various kind of Books that contain moral character are very much needed at this time. Unfortunately, such books are still rarely found in schools, especially in the regions (Marliana \& Suhita, 2017). Hence, the using of story books sustain to increase students' interest in reading while at the same time taking moral values from the stories presented.

Story book is an essay that tells actions, experiences, events aimed at children whose story content is simple, complex and communicative and contains moral values for children (Harvey, 2010; Sari et al., 2021). The magnitude of the role of story book on personality formation can be used for inculcate morals and character (Untari et al., 2012). Storybook media can improve children's literacy and vocabulary skills (Ambarwati \& Asmawati, 2018). The cultivation of morals and character from an early age can improve the condition of the next generation now. Story book is to motivate students in improving literacy skills and vocabulary mastery, help students explore their potential in stimulate reading interest and vocabulary (Ambarwati \& Asmawati, 2018). Story book can be grouped into several types, such as (1) humor is a funny part of folklore that makes the reader laugh (2) Fairy tale is a story based on wishful thinking or fantasy. Fairy tales are stories that live among the people which are presented verbally. (3) Fables are stories that feature animals as the characters. Fables are stories used for moral education. (4) 
Legend is a story that comes from ancient times. Legend stories are related to history in accordance with the reality that exists in nature. (5) Myth is a story related to ancient beliefs, concerning the life of gods or the life of spirits (Rosdiana, 2014).

This research is supported by several relevant studies such as (1) research who obtained the results of the research that strengthening character education is more about the habituation process in practice but is carried out continuously so that it becomes a good habit which must be maintained (Harfiani, 2018). (2) research obtained the result of the reseach that the cultivation of digital literacybased characters is a very urgent thing that should be done in elementary schools. This is marked by four efforts that can be done by the school, among others, are conducive classroom management, implementation of character-based digital literacy, strengthening understanding of character values, and understanding self-concept (Abdullah \& Wicaksono, 2020). (3) research who obtained the results of the research that the role of the principal in the success of the literacy program namely, socializing the policies of the School Literacy Movement through meetings, make a Decree of the School Literacy Team, providing reading corners in classrooms and libraries, always remind about programs, allocate funds for the procurement of books, holding competitions, and requires students to read a book every day for 15 minutes before starting the lesson (Kartini \& Yuhana, 2019). (4) research who obtained the results of the research that an important component of this literacy movement, slowly but surely began to show concern (Agustin \& Cahyono, 2017). The implementation of literacy is carried out in the morning before the first hour or before starting teaching and learning activities. Reading Journal Books are provided in each class, to monitor student progress in literacy activities. From some of these studies, most of the previous studies only describe the implementation of literacy which there is still no research that uses story books in implementation of literacy at school. In line with previous research and also the background described previously, this study aims to analyse and obtain the information about the application of literacy culture at Kartika XX-I Makassar and also implement literacy by using storybook for students.

\section{METHOD}

This research was a qualitative descriptive study with a survey method. According to Creswell, qualitative research is a type of research that explores and understands the meaning of many individuals or groups of people originating from social problems (Rahmasantika \& Prahmana, 2018). The survey method is an investigation conducted to obtain facts from existing symptoms and look for factual deficiencies. The purpose of this survey research is to provide a detailed description of the background, characteristics, and characteristics of a case or event of a general nature. Qualitative research as a human instrument, has the function of determining the focus of research, selecting informants as data sources, collecting data, assessing data quality, analyzing data, interpreting data and making conclusions on the findings (Sugiyono, 2012).

This research was conducted at the Kartika XX-1 Elementary School in Makassar. In this school, there are about 286 students consisting of 151 male students and 135 female students. In this study, the population was all students at SD Kartika XX-1 which consisted of 12 classes with a total of 286 students. The number of samples in this study were 15 students, namely grades IV, V, and VI who were randomly selected. The instrument is a tool used to collect data or information that is useful to answer research problems (Sugiyono, 2012). Instruments in this study used observation, interview guidelines, and documentation.The instruments in the research that will be used are a) observation is a data collection technique that is carried out in which researchers conduct observations and record systematically on the application of literacy culture, the implementation of this observation is carried out to determine the initial conditions of the research location before starting planning, implementation of evaluation and preparation of reports; b) interviews are non-test instruments consisting of a series of questions in which the interviewer only has to mark a checklist on the answer choices that have been prepared. Interviews were addressed to resource persons to explore the data information needed; and c) documentation. This stage aims to support and provide confirmation of the results of observations and interviews.

Tabel 1. The Instrument Grid

\begin{tabular}{lll}
\hline No & Indicator & Number \\
\hline $\mathbf{1}$ & The purposes of literacy & 4,5 \\
$\mathbf{2}$ & The implementation of literacy at the school & $1,2,3$ \\
$\mathbf{3}$ & School availability for literacy & $6,7,8$ \\
$\mathbf{4}$ & Literacy by using story book & 9,10 \\
\hline
\end{tabular}


This data analysis includes (1) Data Reduction. The process of selecting, focusing on simplification, abstracting, and transforming rough data that emerged from written records in the field. Data reduction takes place continuously as long as a qualitatively oriented project takes place, the next reduction stages are summarizing, coding, tracing themes, creating clusters, partitioning, and writing memos, (2) Data Presentation. Presentation as a collection of structured information that gives the possibility of drawing conclusions. Third, data verification. Verification data is carried out by concluding the data related to the research focus accompanied by valid evidence and consistent.

\section{RESULT AND DISCUSSION}

\section{Result}

This part describes the findings regarding to obtain the data about the application of literacy at Kartika XX-I Makassar and also implement literacy by using story book for students at Kartika XX-I Makassar, based on data obtained from observation, interviews, and documentation. Based on the results of observations and interview, it was found that the implementation of literacy in this school had been carried out around 2017. The existence of a positive response and good cooperation from all stakeholders is a balanced combination in creating a literacy culture at SD Kartika XX-I Makassar. This school implements literacy days on an ongoing basis, this activity is carried out jointly and continuously which is carried out from grade I to grade VI. The purpose of this activity is to get used to reading aloud which is done together and students are expected to be able to tell the contents of the readings that have been read. The implementation of School Literacy has been carefully prepared, including a reading schedule that has been arranged by the teacher and the library with the approval of the principal.

Table 2. Literacy Activities at SD Kartika XX-I Makassar

Literacy Activities
Reading 15 minutes before class starts
a. Reading together in the school hall

\section{b. Reading in class}

Organizing literacy facilities and environment; School library, Class reading corner, Reading area and Slogans

Choosing reading books in the school

\section{Implementation at the school}

a. Found books in the library to be read aloud every Tuesday and Thursday before class begins.

b. Read the textbook silently every wednesday before class starts.

SD Kartika XX-I Makassar already has a fairly large library, a reading corner, a student reading area which is quite liked by students, and many slogans are affixed or hung in the school area.

It has been done quite optimally because the reading books are quite varied from textbooks or short stories. The books were obtained from education volunteers in Makassar and also donations from students' parents. It's just that changing the various of the book is not sustainable.

Table 2 explains that the implementation of literacy at the school was carried out for fifteen minutes before learning begins and it was carried out twice a day. On Tuesday, students were asked to gather in the hall to read books together accompanied by teachers and the books were prepared by the school. On Thursday, students carried out literacy in their classes by reading textbooks or books in the reading corner in each class. In implementing literacy, the school had prepared facilities that can support the achievement of literacy both indoors and outdoors. The school prepared a library room that is large enough, so that students feel comfortable while reading. Morever, the library has been continuesly borrowing and returning books to students. Each class was equipped with a reading corner with various types of books. The school has provided a reading area around the school that students can take advantage of. And also put reading boards in several corners of the school. Based on the results of documentation, the implementation of literacy by using story book was carried out by online meeting.

The implementation of this research was carried out during the Covid 19 pandemic. However, the researchers worked to design the research as best as possible which is the literacy was carried out by using video conference. This implementation was done by sending a story book file to each student. The storybook consists of several titles of folk tales in it. Students were asked to choose the title of the story that they liked the most. Reading was done depending on their learning style, namely reading aloud and 
reading in the day. After being given time, students were asked to retell the story and determine the Morals presented in the story. It made students interested in reading.

\section{Discussion}

Literacy movement is a government program to raise the spirit of literacy culture in schools. Implementation of literacy can help students find out a variety of knowledge. This is in accordance with the research had been carried out that the Implementation of Literacy activities could build their knowledge and values based on the topics they read, and support a person in developing himself (Farikah, 2019; Mumpuni et al., 2021). Through literacy activities, the nation's young generation can become better individuals with various insights and knowledge gained (Wahyuni et al., 2018). Thus, the initial understanding of literacy is to familiarize children with developing an interest in reading, the potrait of the implementation of literacy at SD Kartika has been carried out well by implementing several facilities and programs. This is in according with government program recommendations to improve and cultivate literacy because school as a learning organization (Agustin \& Cahyono, 2017; Erniyanti, 2018). The implementation of literacy programs conducted at the school such as the application of fifteen minutes reading before starting the lesson. This was in line with the research results showed that Literacy activities at the school are carried out to foster interest in reading through 15-minute reading activities (Kartini \& Yuhana, 2019; Syawaluddin \& Nurhaedah, 2017). Basically, School Literacy Activities really support School Development Programs, because with literacy students are better trained to understand the books or readings they read. Literacy culture is also supported by means of supporting literacy activities, several facilities are provided at SD Kartika such as a library used for learning, reading corners in each class, reading area placed in the school yard and also reading boards or slogans around the school. This was in line with the research results that showed that who said that reading corners, reading areas, and school libraries are physical facilities that can support the school literacy movement (Erniyanti, 2018; Kastro, 2020). The application of the literacy movement for students in the school environment is very useful. It can help students to know many things, knowledge and add new vocabulary. It is related with the opinion that the School Literacy Movement is truly beneficial for students, Students start reading on occasion (Arini et al., 2020). Hence, it is necessary to support the implementation of literacy with various facilities.

In this research, the implementation of literacy using storybooks was done by gathering students to read. Reading material contains moral values, in the form of local, national, and global wisdom that is delivered according to the stage of development of students. It was in line the opinion that giving stimulation to children during the process of personality development is very important (Ahyani, 2010). One of the necessary and important stimulations for children is the inculcation of moral values and the inculcation of moral values is very necessary for the development of their moral intelligence. Reading story book makes easier for students to retell the contents which indicates th at they are doing literacy at the moment. This description was in line with the opinion said that students can improve their literacy and identify the moral value by using storybook (Harvey, 2010; Sari et al., 2021). The application of literacy using story books can make students interested in reading. Reading story book is able to invite students to retell the contents of the story and take the moral values that exist in the story (Syarif et al., 2016; Untari et al., 2012) and by having literacy skills young leaner can share what they have learnt and have known to others (Souisa et al., 2020).

The integration of cultural and moral values in the learning process has an important meaning in shaping the personality of students. And elementary school is a time when children are in the golden age, so, it is very important to instill a reading culture and noble character values. This was in line with the opinions that elementary school is a time when children are in the golden age (Suyadi, 2010; Wahab \& Amaliyah., 2019), so it is very important to instill a reading culture and noble character values, and also skills (Ambarwati \& Asmawati, 2018). Story books are very effectively used to improve children's moral intelligence and improve children's literacy skills and contain folklore is a kind of teaching and learning materials that can be applied to build learners' literacy (Souisa et al., 2020). From some of the activities that have been described, it can be seen that the implementation of literacy culture at the school has been quite effective. Changing habits or culture is not as easy as turning the hand, it needs a comprehensive movement and of course supported by all parties involved. The social and cultural background of the community greatly influences the success of this activity. Students who initially liked reading were certainly easy to adapt to literacy activities, but students who initially did not like reading, would have difficulty adopting this literacy activity. That cultivating or getting used to reading, let alone writing needs a process, if in a community group the habit does not yet exist or has not been formed. So all elements are expected to support the success of this literacy activity, work together to get used to reading, which in the end creates a new culture, namely literacy habits. 
There are many goals to be achieved in the implementation of literacy in schools which are packaged in literacy activity, including starting from low interest in reading in the eyes of the world. Therefore, the reading culture is expected to increase students' knowledge. One of the supporting factors for the implementation of literacy activities at the school is the support of several agencies or volunteers who collaborate with schools to donate the various title of books. It This was in line with the opinions that schools must present a variety of reading books and accommodate various reading strategies to support learning (Batubara \& Ariani, 2018; Suragangga, 2017). In addition to supporting factors, there are also obstacle factors for literacy activities at the school. The obstacles faced in implementing literacy such as the use of the library which must be optimized and the title of the book is changed regularly. The procurement of books has not been sustainable and also although the school has programmed the literacy movement in schools, some students feel less interested in reading because of the lack of variety of book titles available at school. It lines with the opinion when children can read a variety of different books they can draw conclusions from what they read (Ismaniar et al., 2019; Sinaga et al., 2021). Thus, it is needed for a supply of books that vary not only in knowledge but also in increasing the types of story books.

\section{CONCLUSION}

There are several applications of literacy culture carried out at the school including requiring a reading corner in every class, applying 15 minutes of literacy culture before the teaching and learning process. The application of literacy with storybooks. This way can help students to apply literacy around the school. The support from all school members such as principal, teachers and the environment are quite effective to cultivate literacy in the school environment. Story book is a kind of book that contain moral values that can build students' character from an early age. Implementation of literacy using story books can attract students' interest to read and stimulate students' ability to retell it using their own words.

\section{REFERENCES}

Abdullah, S., \& Wicaksono, J. W. (2020). Urgensi Pendidikan Karakter Berbasis Literasi Digital pada Siswa SDN 39 Kota Ternate. Prosiding Seminar dan Diskusi Nasional Pendidikan Nasional 2020. http://journal.unj.ac.id/unj/index.php/psdpd/article/view/17743.

Agustin, S., \& Cahyono, B. E. (2017). Gerakan Literasi Sekolah untuk Meningkatkan Budaya Baca di SMA Negeri 1 Geger. Linguista, 1(2), 55-62. https://doi.org/10.25273/linguista.v1i2.1973.

Ahyani, L. N. (2010). Metode Dongeng dalam Meningkatkan Perkembangan Kecerdasan Moral Anak Usia Prasekolah. Jurnal Psikologi, 1(1). https://jurnal.imk.ac.id/index.php/PSI/article/view/22 .

Ambarwati, A., \& Asmawati, L. (2018). Peningkatan Kemampuan Literasi dan Penguasaan Kosakata melalui Media Buku Cerita Anak Berbasis Kearifan Lokal Banten pada Anak Usia Dini. Jurnal Teknologi Pendidikan Dan Pembelajaran, https://jurnal.untirta.ac.id/index.php/JTPPm/article/view/7467.

Arini, N. W., Dibia, I. K., \& Bayu, I. G. (2020). School Literacy Movement Enhancing Students' Writing Skills and Creative Thinking Skills. Jurnal Ilmiah Sekolah Dasar, 4(4), 546-552. https: //ejournal.undiksha.ac.id/index.php/JISD/index.

Batubara, H. H., \& Ariani, D. N. (2018). Implementasi Program Gerakan Literasi Sekolah di Sekolah Dasar Negeri Gugus Sungai MIAI Banjarmasin. Jurnal Pendidikan Sekolah Dasar, 4(1). https: //jurnal.untirta.ac.id/index.php/jpsd/article/view/2965.

Erniyanti. (2018). Implementasi Gerakan Literasi Sekolah dan Pendidikan Karakter Ditinjau dari Pembelajaran Bahasa Indonesia di Sekolah Dasar. Jurnal Teknologi Pendidikan Dan Pembelajaran, 5(2), 112-122. https://jurnal.untirta.ac.id/index.php/JTPPm/article/view/7479.

Farikah. (2019). Developing the Students' Character through Literacy Activities in a Child-Friendly School Model. Dinamika Ilmu, 19(2), 187-196. https://doi.org/10.21093/di.v19i2.1540.

Harfiani, A. (2018). Penguatan Pendidikan Karakter melalui Budaya Literasi dalam Konteks Pembelajaran Abad 21 di Sekolah Dasar. Prosiding Seminar Dan Diskusi Nasional Pendidikan Dasar, 141-150. http://journal.unj.ac.id/unj/index.php/psdpd/article/view/10002.

Harvey, J. G. (2010). The Literacy Myth: Literacy, Education, and Demography. V. Y. Research, Demographic Debate, 17-23. https://doi.org/10.1553/population yearbook 201017.

Ismaniar, Jamaris, \& Wisroni. (2019). Improving Children's Early Reading Skills Using Home Environmental Print Model. Proceedings of the 5th International Conference on Education and Technology (ICET 2019) Advances in Social Science, Education and Humanities Research, 403-406. https: //doi.org/10.2991/icet-19.2019.101.

Izati, S. N., Wahyudi, \& Sugiyarti, M. (2018). Project Based Learning Berbasis Literasi untuk Meningkatkan 
Hasil Belajar Tematik. Jurnal Pendidikan, 3(9), 1122-1127. https://doi.org/10.17977/jptpp.v3i9.11508.

Kartini, D., \& Yuhana. (2019). Peran Kepala Sekolah dalam Menyukseskan Program Literasi. Jurnal Manajemen, Kepemimpinan dan Supervisi Pendidikan, 4(2), 137-144. https://doi.org/10.31851/jmksp.v4i2.2902.

Kastro, A. (2020). Peranan Perpustakaan Sekolah sebagai Sarana Pendukung Gerakan Literasi Sekolah di Sekolah Menengah Pertama. Jurnal Kajian Pembelajaran dan Keilmuan, 4(1), 92-100. https://jurnal.untan.ac.id/index.php/jurnalkpk/issue/view/1290.

Khotimah, K., Akbar, S., \& Sa'dijah, C. (2018). Pelaksanaan Gerakan Literasi Sekolah. Jurnal Pendidikan: Teori, Penelitian, Dan Pengembangan, 3(11), 1488-1498. https://doi.org/10.17977/jptpp.v3i11.11778.

Marliana, N. L., \& Suhita, S. (2017). Pengembangan Program Gerakan Literasi Sekolah bagi Para Siswa SDN Cinyosog 01 Cileungsi. Tuturan, 6(1), 762-770. https://doi.org/10.33603/jt.v6i1.1586.

Mumpuni, A., Kurniawan, P. Y., Nurbaeti, R. U., Fadillah, A. N., Yuliyanti, M., \& Indriyani, N. (2021). Implementation of the School Literacy Mocement during the Covid-19 Pandemic. Premiere Educandum: Journal of Basic Education and Learning, 11(1), 75-86. http://ejournal.unipma.ac.id/index.php/PE/article/view/7928/0.

Novarina, G. E., Santoso, A., \& Furaidah. (2019). Model Pelaksanaan Gerakan Literasi Sekolah di Sekolah Dasar. Jurnal Pendidikan: Teori, Penelitian, dan Pengembangan, 4(11), 1448-1456. https://doi.org/10.17977/jptpp.v4i11.12989.

Nurhadi. (2016). Teknik Membaca. Bumi Aksara.

Rahmasantika, D., \& Prahmana, R. C. (2018). Analisis Kesalahan Siswa pada Operasi Hitung Pecahan Berdasarkan Tingkat Kecerdasan Siswa. Journal of Honai Math, 1(2), 81-92. https: //journalfkipunipa.org/index.php/jhm/article/view/14/11.

Rosdiana, Y. (2014). Bahasa dan Sastra Indonesia di SD: Hakikat Bahasa. http://repository.ut.ac.id/4008/.

Sari, A., Nainggolan, E. S., Maharini, M. T., Merilia, S., \& Wirharyati. (2021). Pengenalan nilai budaya dengan Menggunakan Cerita Rakyat untuk Meningkatkan Literasi Bahasa Inggris di Taman Bacaan Masyarakat (TBM) Ciputat. Acitya Bhakti Jurnal Pengabdian Kepada Masyarakat, 1(1). http://openjournal.unpam.ac.id/index.php/ACB/article/view/9127.

Silvia, O. W., \& Djuanda, D. (2017). Model Literature Based dalam Program Gerakan Literasi Sekolah. Mimbar Sekolah Dasar, 4(2), 160-171. https://doi.org/10.53400/mimbar-sd.v4i2.7799.

Sinaga, E. S., Dhieni, N., \& Sumadi, T. (2021). Pengaruh Lingkungan Literasi di Kelas terhadap Kemampuan Membaca Permulaan Anak. Jurnal Obsesi: Jurnal Pendidikan Anak Usia Dini, 6(1), 279-287. https://obsesi.or.id/index.php/obsesi/article/view/1264.

Souisa, T. R., Lekatompessy, J., \& Ferdinandus, M. (2020). Diglot Picture Storybook Based on Maluku Content and Its Relevance for Young Learners' Literacy. Jurnal Tahuri, 17(2), 84-95. https: //doi.org/10.30598/tahurivol17issue2page84-95.

Sugiyono. (2012). Metode Penelitian Pendidikan (Pendekatan Kuantitatif, Kualitatif dan R\&D. Alfabeta.

Suragangga, I. M. N. (2017). Mendidik Lewat Literasi untuk Pendidikan Berkualitas. Jurnal Penjaminan Mutu, 3(2), 154-163. https://doi.org/10.25078/jpm.v3i2.195.

Suyadi. (2010). Psikologi Belajar Anak Usia Dini. Pedagogia.

Suyono. (2011). Pembelajaran Efektif dan Produktif Berbasis Literasi: Analisis Konteks, Prinsip, dan Wujud Alternatif Strategi Implementasinya di Sekolah. Penerbit Cakrawala Indonesia.

Suyono, Harsiati, T., \& Wulandari, I. S. (2017). Implementasi Gerakan Literasi Sekolah pada Pembelajaran Tematik di Sekolah dasar. Jurnal Sekolah Dasar Kajian Teori dan Praktik Pendidikan, 26(2), 116123. https://doi.org/10.17977/um009v26i22017p116.

Syarif, E., Sumarmi., Fatchan, A., \& Astina, K. (2016). Integrasi Nilai Budaya Etnis Bugis Makassar dalam Proses Pembelajaran sebagai Salah Satu Strategi Menghadapi Era Masyarakat Ekonomi Asean (MEA). Jurnal Teori dan Praksis Pembelajaran IPS, 1(1). https: //doi.org/10.17977/um022v1i12016p013.

Syawaluddin, A., \& Nurhaedah. (2017). Pengaruh Gerakan Literasi Sekolah (GLS) terhadap Kemampuan Literasi Siswa Kelas V SD Negeri Gunung Sari I Kecamatan Rappocini Kota Makassar. International Journal of Elementary Education. International Journal of Elementary Education, 1(4), 238-243. https://doi.org/10.23887/ijee.v1i4.12964.

Tryanasari, D., Aprilia, S., \& Cahya, W. A. (2017). Pembelajaran Literasi di SDN Rejosari 1 Kecamatan Kawedanan Kabupaten magetan. Jurnal Pendidikan Dasar dan Pembelajaran, 7(2), 173-179. https://doi.org/10.25273/pe.v7i2.1641.

Untari, M. F. A., Supriyabto, T., \& Mardikantoro, H. B. (2012). Pengembangan Cerita Anak Berwawasan Budi Pekerti bagi Pendidikan Karakter. Primary Education Journal, 12(1), 1-5. 
https://doi.org/10.15294/jpe.v1i1.47.

Wahab, I., \& Amaliyah., N. (2019). Identifikasi Cerita Anak Berbasis Budaya Lokal untuk Membudayakan $\begin{array}{lllll}\text { Literasi } & \mathrm{di} & \text { SD. Jurnal } & \text { Satya }\end{array}$ https://doi.org/10.24246/j.sw.2019.v35.i2.p176-185.

Wahyuni, P. D., Djatmika, E. T., \& As'sari, A. R. (2018). Pengaruh Full Day School dan Gerakan Literasi Sekolah terhadap Hasil Belajar dengan Mediasi Motivasi Belajar. Jurnal Pendidikan, 3(5), 679-684. https://doi.org/10.17977/jptpp.v3i5.11096.

Warsihna, J. (2016). Meningkatkan Literasi Membaca dan Menulis dengan Teknologi Informasi dan Komunikasi (TIK). Jurnal Teknologi Pendidikan, 4(2), 67-80. https://jurnalkwangsan.kemdikbud.go.id/index.php/jurnalkwangsan/article/view/84/65.

Yulianti, A., Effendy, U., \& Yosef. (2018). Gerakan Literasi Sekolah di SD Negeri 157 Palembang. Jurnal Kajian Pengembangan Pendidikan, 5(1). https://doi.org/10.36706/jisd.v5i1.8257.

Yunianika, I. T., \& Suratinah. (2019). Implementasi Gerakan Literasi Sekolah di Sekolah Dasar Dharma Karya Universitas Terbuka. Jurnal Ilmiah Sekolah Dasar, 3(4), 497-503. https://doi.org/10.23887/jisd.v3i4.17331. 